\title{
ANALISIS DAMPAK PERUBAHAN IKLIM TERHADAP PRODUKSI BERAS PROVINSI SULAWESI UTARA TAHUN 2013 - 2030
}

\section{ANALYSIS OF THE CLIMATE CHANGE IMPACT ON RICE PRODUCTION OF THE PROVINCE OF NORTH SULAWESI IN 2013 - 2030}

\author{
Peter Rene Hosang1), J. Tatuh2), dan Johannes E. X. Rogi2) \\ 1)Badan Ketahanan Pangan Provinsi Sulawesi Utara \\ 2)Fakultas Pertanian UNSRAT Manado
}

\begin{abstract}
Climate change has caused in the decreasing of rice production worldwide which affects food security condition in North Sulawesi. Therefore, efforts need to be done to anticipate this issue. A combination of numerical and spatial models was chosen in this study. Paddy rice numerical simulation model described relationships between crops' physical environmental conditions and physiological condition in the forms of mathematical equations. Model inputs included climatic components, such as: light, temperature, humidity, wind speed and rainfall; soil physical components including: soil capacity, permanent wilt point, soil evaporation parameter; soil chemical variables including: $\mathrm{pH}$ and total nitrogen; agronomical input including: crop varieties, seed growth rate, irigation and nitrogen fertilizer; initial conditions including: ground water concentration, mineral nitrogen $\left(\mathrm{NH}_{4}\right.$ and $\left.\mathrm{NO}_{3}\right)$ from various soil layers. Model output can be determined based on the purpose of the study. This research concluded that (a) rainfall pattern change and temperature's increase affected paddy rice production, (b) 141,677 ton of rice shortage will be occurred in 2030. Strategics to anticipate this condition should be formulated. It is recommended to conduct a further research on compiling climate change data in North Sulawesi. Also, it is crucial to produce best paddy rice varietas resistant of climate change through biotechnology.
\end{abstract}

Keywords : climate change, produce

\section{ABSTRAK}

Perubahan iklim mengakibatkan terjadi gangguan dalam produksi tanaman padi yang mempengaruhi kondisi ketahanan pangan di Sulawesi Utara sehingga perlu adanya langkah-langkah mengantisipasinya. Metode penelitian dilakukan dengan menggunakan pendekatan yang mengintegrasikan model numerik dan spasial. Model numerik simulasi tanaman padi menjelaskan hubungan antara kondisi fisik lingkungan dengan kondisi fisiologis tanaman dalam bentuk persamaanpersamaan matematis. Input model terdiri dari unsur-unsur cuaca berupa radiasi surya, suhu dan kelembaban udara, kecepatan angin dan curah hujan; sifat fisik tanah (kapasitas lapang, titik layu permanen dan parameter evaporasi tanah); sifat kimia tanah ( $\mathrm{pH}$, nitrogen total); input agronomis (varietas, laju penggunaan benih, irigasi, pemupukan nitrogen); serta kondisi awal berupa kadar air tanah dan nitrogen mineral $\left(\mathrm{NH}_{4}\right.$ dan $\left.\mathrm{NO}_{3}\right)$ dari berbagai lapisan tanah. Sedangkan untuk output dapat disesuai dengan tujuannya. Penelitian ini dapat disimpulkan bahwa (a) perubahan pola curah hujan dan kenaikan suhu udara mempengaruhi produksi tanaman padi, (b) prognosa ketersediaan beras pada tahun 2030 mengalami defisit sebesar 141,677 ton, sehingga diperlukan langkah strategi untuk mengantisipasi.

Kata kunci : perubahan iklim, produksi 


\section{PENDAHULUAN}

Masalah pangan saat ini sudah menjadi ancaman bagi ketahanan pangan dunia. Cuaca ekstrim yang melanda berbagai negara di dunia termasuk Indonesia, menjadi indikator terhadap masalah pangan yang serius di kemudian hari. Perubahan iklim merupakan sesuatu yang sulit untuk dihindari dan memberikan dampak terhadap berbagai segi kehidupan. Perubahan dan anomali iklim mempengaruhi kemampuan dan dinamika produksi pertanian. Perubahan iklim yang agak dominan pengaruhnya terhadap ketahanan pangan yaitu pergeseran musim hujan atau kemarau yang sangat mempengaruhi pola dan waktu tanam tanaman semusim yang umumnya ialah tanaman pangan. Gejala pemanasan global yang terjadi saat ini lebih disebabkan oleh kegiatan manusia (Antropogenic).

Perubahan iklim ditandai tidak hanya suhu yang semakin tinggi tetapi juga curah hujan yang semakin berkurang dan tidak menentu. Meningkatnya suhu udara global yang dimulai sejak revolusi industri tahun 1750 dan sampai saat ini telah mencapai $0,7^{\circ} \mathrm{C}$, prediksi para ahli di bidang ikilm menunjukkan bahwa kenaikan suhu udara $1^{\circ} \mathrm{C}$ sampai $1,5^{\circ} \mathrm{C}$ tidak dapat terelakan lagi.

Lembaga Penelitian Padi di Philipina melaporkan bahwa peningkatan suhu $1^{\circ} \mathrm{C}$ mengakibatkan panen padi turun $10 \%$ dan ini mengancam ketersediaan pangan penduduk dunia dan tanpa tindakan apa-apa suhu dapat meningkat $5^{\circ} \mathrm{C}$. Namun perubahan iklim global belum memberikan dampak yang signifikan terhadap produksi pangan khususnya beras di wilayah Sulawesi Utara. Hal ini ditunjukkan dengan adanya peningkatan produksi padi diatas $5 \%$ setiap tahunnya. Namun dengan adanya perubahan iklim global yang pasti akan memberikan dampak terhadap pemantapan ketahanan pangan secara nasional maupun regional khususnya di Sulawesi Utara, maka perlu dilakukan langkah-langkah antisipatif dalam rangka memenuhi ketersediaan dan kebutuhan pangan khusus beras di masa yang akan datang, antara lain dengan melihat kemampuan dan dinamika produksi pertanian yang dipengaruhi oleh perubahan dan anomali iklim.
Pendugaan dampak perubahan iklim terhadap produksi beras di Sulawesi Utara untuk skenario ke depan dapat menggunakan model simulasi. Model simulasi digunakan untuk menjelaskan proses dalam suatu sistem pertanaman pada berbagai tingkat kompleksitas dan bersifat fleksibel di dalam sintesis informasi karena dapat menerangkan keluaran sistem atas masukan sistem yang berupa faktor-faktor lingkungan dan penerapan teknik budidaya. Rogi (2002) mengatakan bahwa tujuan model simulasi tanaman dapat dibagi dalam dua kelompok, yaitu: 1) meningkatkan pemahaman tentang interaksi fisiologi dan lingkungan tanaman, 2) memberikan informasi tentang cara-cara manajemen bagi petani ataupun memberikan prediksi-prediksi bagi para pengambil keputusan. Djufry (2001) mengatakan bahwa dengan model simulasi, tanggapan hasil tanaman terhadap tanah, cuaca, dan pengolahan dapat diperkirakan. Karena sifatnya tersebut maka aplikasi model simulasi memiliki kelebihan kemampuan prediksi karena menggunakan pendekatan kuantitatif dan dapat diterapkan pada skala yang luas.

Ketahanan pangan merupakan suatu sistem yang terdiri dari 3 (tiga) sub sistem yaitu sub sistem ketersediaan pangan, sub sistem distribusi pangan dan sub sistem konsumsi pangan. Ketiga sub sistem tersebut memiliki aspek penunjang yaitu aspek produksi dan cadangan pangan untuk menunjang sub sistem ketersediaan pangan, aspek aksesibilitas dan harga pangan untuk menunjang sub sistem distribusi pangan serta aspek diversifikasi konsumsi dan keamanan pangan untuk menunjang sub sistem konsumsi pangan.

Aspek produksi yang menunjang sub sistem ketersediaan pangan sangat dipengaruhi oleh beberapa faktor antara lain iklim, ketersediaan lahan dan air, serta sifat fisik tanah. Untuk mempertahankan produksi pangan, maka perlu dilakukan upaya-upaya penanganan untuk meminimalisir terjadinya gangguan produksi pangan yang dapat mengakibatkan terjadinya masalah kekurangan pangan.

Perubahan iklim yang terjadi saat ini, sangat berdampak pada produksi pangan antara lain komoditas padi, sehingga perlu dilakukan langkah-langkah antisipasi masalah ketersediaan 
beras untuk memenuhi kebutuhan beras penduduk di masa yang akan datang.

Penelitian ini bertujuan untuk menghitung kebutuhan beras Provinsi Sulawesi Utara Tahun 2013-2030 dan melakukan skenario perubahan iklim untuk melihat perkembangan produksi beras di Provinsi Sulawesi Utara

Manfaat penelitian yaitu sebagai pedoman program perberasan di Sulawesi Utara

\section{METODE PENELITIAN}

Penelitian ini dilakukan di lingkup wilayah analisis Sulawesi Utara, yang berlangsung pada bulan Agustus 2012.

Bahan dan alat yang digunakan yaitu : Peta Administrasi Provinsi Sulawesi Utara; GPS (Geoposition System); Model simulasi tanaman Padi Shierary Rice; dan Model pembangkit cuaca Shierary Whether yang dikembangkan Handoko tahun 1994.

Metode penelitian dilakukan dengan menggunakan model Shierary Rice.

Model Shierary Rice merupakan alat analisis kuantitatif dalam hubungan pertumbuhan tanaman dengan lingkungannya (iklim dan tanah). Unsur-unsur yang digunakan dalam model ini adalah suhu, curah hujan dan produksi.

\section{HASIL DAN PEMBAHASAN}

\section{Prognosa Ketersediaan Beras Tahun 2013-2030}

Berdasarkan hasil penelitian, menunjukkan bahwa produktivitas padi mengalami penurunan yang dipengaruhi oleh suhu udara dan curah hujan, sebagaimana pada Tabel 1 .

Tabel 2 menunjukkan bahwa ketersediaan beras mengalami defisit mulai tahun 2020 sebesar 37,397 ton, tahun 2025 sebesar 84,681 ton dan tahun 2030 sebesar 141,677 ton.

Untuk menganalisis lebih lanjut tentang ketersediaan beras sampai dengan tahun 2030, maka dilakukan simulasi dengan menggunakan beberapa asumsi yaitu luas lahan tidak mengalami perubahan dari tahun ke tahun yaitu sebesar 55.000 ha; kenaikan luas lahan sebesar 500 ha per tahun, 1.000 ha per tahun dan 2.000 ha per tahun. Hasil analisis dengan asumsi tersebut sebagai berikut : 1) Asumsi luas lahan tidak mengalami perubahan, menunjukkan ketersediaan beras mengalami surplus pada tahun 2012 dan 2013 masing-masing sebesar 53,624 ton dan 29,131, sedangkan pada tahun 2020 sampai dengan 2030 sudah mengalami defisit masing-masing sebesar 16,237 ton, 55,106 ton dan 109,817 ton; 2) Asumsi luas lahan naik 500 ha/tahun, menunjukkan ketersediaan beras mengalami surplus pada tahun 2012, 2013 dan 2020 masing-masing sebesar 53,624 ton; 32,296 ton dan 4,922 ton sedangkan pada tahun 2025 sampai dengan 2030 sudah mengalami defisit masing-masing sebesar 25,531 dan 77,957 ton; 3) Asumsi luas lahan naik 1.000 ha/tahun, menunjukkan ketersediaan beras mengalami surplus pada tahun 2012, 2013, 2020 dan 2025 masing-masing sebesar 53,624 ton; 35,461 ton; 26,082 ton dan 4,043 sedangkan pada 2030 mengalami defisit sebesar 46,097 ton; 4) Asumsi luas lahan naik 2.000 ha/tahun, menunjuk-kan ketersediaan beras mengalami surplus mulai tahun 2012, 2020, 2025 dan tahun 2030 masing-masing sebesar 53,624 ton; 41,791 ton; 68,402 ton; 63,193 ton dan 17,622 ton.

Memperhatikan kondisi ketersediaan beras sampai dengan tahun 2030 maka perlu dilakukan langkah-langkah strategis untuk mengantisipasi ketahanan pangan, antara lain melakukan ekstensifikasi, diversifikasi konsumsi pangan yang berbasis pangan lokal, meningkatkan produktivitas tanaman padi melalui penggunaan bibit unggul yang tahan pada kondisi suhu tinggi, serta meminimalisir alih fungsi lahan dengan melakukan kebijakan tata ruang wilayah pertanian.

\section{Curah Hujan di Sulawesi Utara}

Iklim di daerah Sulawesi Utara termasuk dalam iklim tropis yang dipengaruhi oleh angin Munson. Pada bulan Oktober sampai dengan Maret bertiup angin dari belahan bumi bagian utara yang membawa massa udara basah sehingga musim hujan identik pada bulan-bulan tersebut, sedangkan pada bulan April sampai September bertiup angin dari belahan bumi bagian selatan yang kering. Curah hujan tidak merata dengan angka tahunan berkisar antara 1223-4989 mm, dan jumlah hari hujan antara 84-305 hari (Daniel B., 2011). 
Tabel 1. Produktivitas Padi Tahun 2013 - 2030 Berdasarkan Hasil Penelitian

(Table 1. Produktivity of Rice in 2013-2030 Based on the Results of Research)

\begin{tabular}{ccccc}
\hline & \multicolumn{4}{c}{ Tahun } \\
\cline { 2 - 5 } Produktivitas $(\mathrm{Ton} / \mathrm{Ha})$ & 2013 & 2020 & 2025 & 2030 \\
\cline { 2 - 5 } & 6,33 & 5,29 & 4,56 & 3,54 \\
\hline
\end{tabular}

Tabel 2. Analisis Kondisi Ketersediaan Beras Pada Tahun 2012 - 2030 (Asumsi luas lahan turun 500 ha/tahun)

(Table 2. Analysis of The Conditions of Supply of Rice In 2012-2030 (Assuming Land Area Fall $500 \mathrm{Ha} / \mathrm{year}$ ))

\begin{tabular}{lrrrrr}
\hline & \multicolumn{1}{c}{2012} & \multicolumn{1}{c}{2013} & \multicolumn{1}{c}{2020} & \multicolumn{1}{c}{2025} & \multicolumn{1}{c}{2030} \\
\hline Produksi (Kg) & $377,300,000$ & $344,985,000$ & $269,790,000$ & $220,675,000$ & $162,840,000$ \\
$\begin{array}{l}\text { Luas Lahan (Ha) } \\
\text { Konsumsi }\end{array}$ & 55,000 & 54,500 & 51,000 & 48,500 & 46,000 \\
$\begin{array}{l}\text { (Kg/Kapita/ } \\
\text { Tahun) }\end{array}$ & 139 & 137 & 123 & 114 & 106 \\
$\begin{array}{l}\text { Penduduk } \\
\text { Kebutuhan (Kg) }\end{array}$ & $2,328,601$ & $2,328,601$ & $2,497,462$ & $2,678,569$ & $2,872,809$ \\
\hline $\begin{array}{l}\text { Defisit/Surplus } \\
\text { (Kg) }\end{array}$ & $53,675,605$ & $319,018,304$ & $307,187,868$ & $305,356,882$ & $304,517,770$ \\
\hline
\end{tabular}

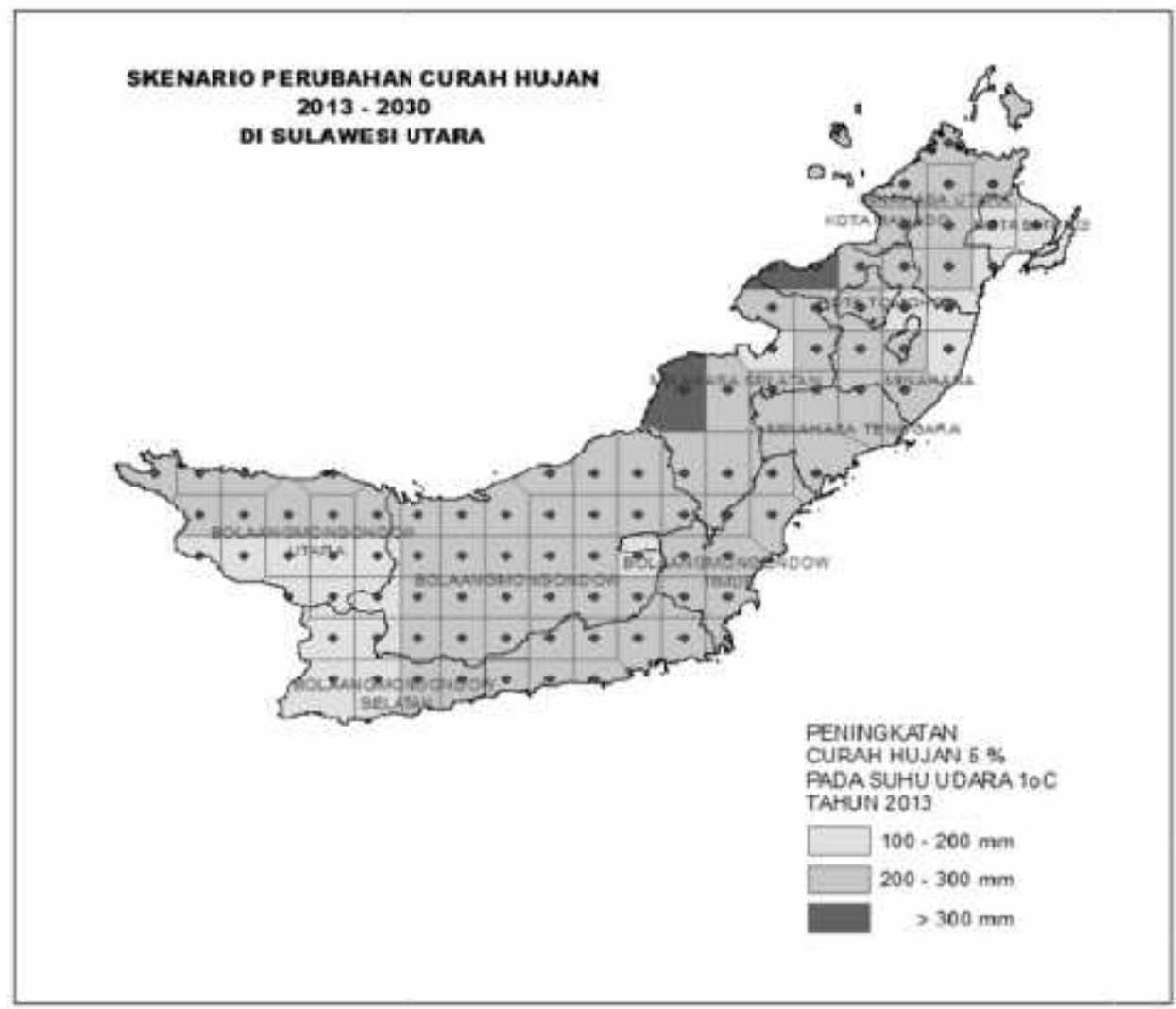

Gambar 1. Curah Hujan Saat Ini di Sulawesi Utara

(Figure 1. Current Rainfall In North Sulawesi) 


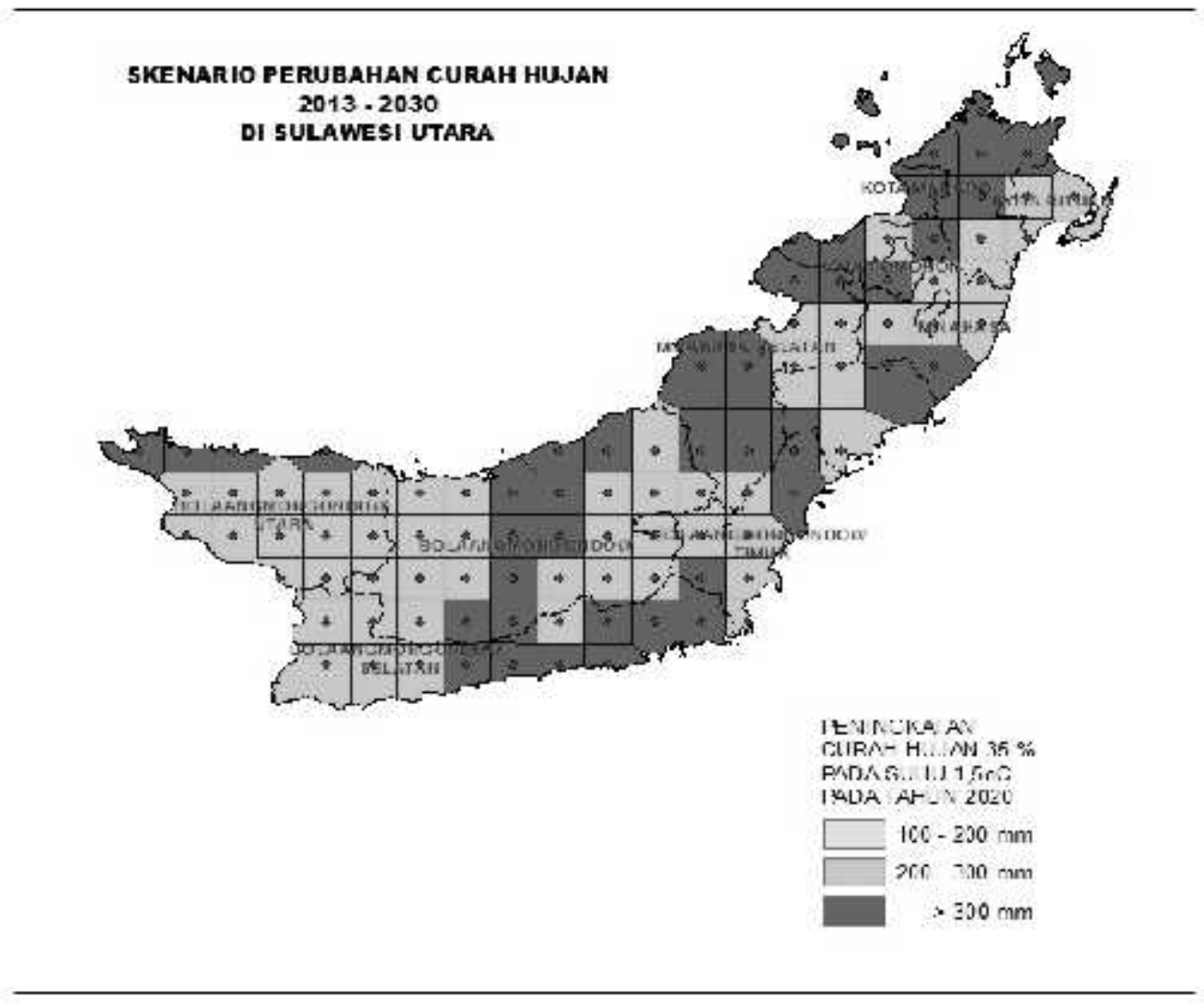

Gambar 2. Skenario Hujan 2012-2030 di Sulawesi Utara

(Figure 2. 2012-2030 Rainfall Scenario In North Sulawesi)

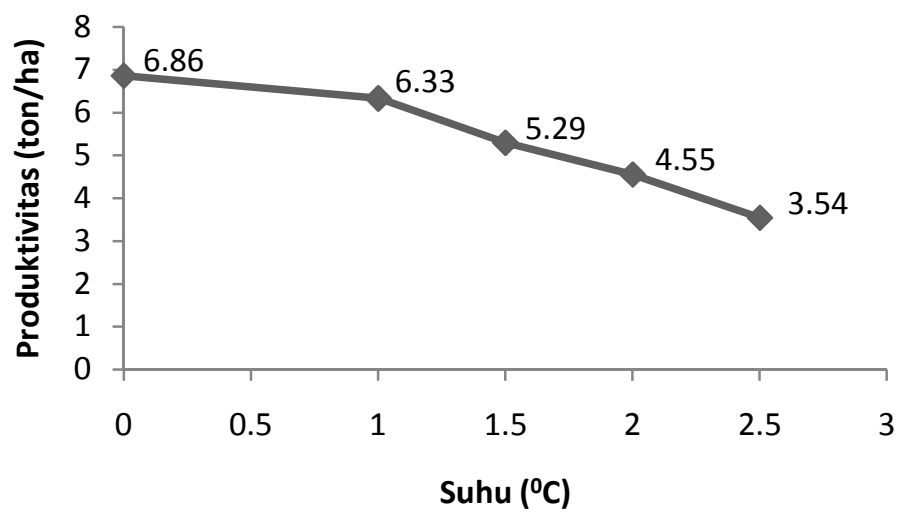

Gambar 3. Hasil Simulasi Produksi Padi Dengan Skenario Menaikkan Suhu Udara $\left(0^{\circ} \mathrm{C}, 1^{\circ} \mathrm{C}, 1,5^{\circ} \mathrm{C}, 2^{\circ} \mathrm{C}, 2,5^{\circ} \mathrm{C}\right)$ (Figure 3. Simulasi Results With The Scenario Of Increasing Rice Production Temperature)

Hasil skenario dengan menaikkan curah hujan rata-rata $5 \%$ pertahun (Gambar 1 dan Gambar 2). (Data BMKG menunjukkan bahwa curah hujan saat ini meningkat $115 \%$ dibandingkan 20 Tahun yang lalu) terlihat bahwa makin banyak daerah yang memiliki curah hujan di atas $300 \mathrm{~mm}$.

\section{Dinamika Suhu Udara}

Hasil simulasi suhu udara terlihat pada Gambar 3, yang menunjukkan bahwa produksi padi mengalami penurunan jika suhu udara dinaikkan rata-rata $0,5^{\circ} \mathrm{C}$ setiap lima tahun, ini disebabkan oleh pengaruh peningkatan curah hujan dan suhu udara terhadap produksi padi. Penurunan produksi 
padi disebabkan oleh terganggunya proses fisiologis (fotosintesis dan respirasi) di tanaman. Pengaruh suhu terhadap pertumbuhan terutama pada respirasi. Dalam proses respirasi, hasil fotosintesis akan diubah menjadi $\mathrm{CO}_{2}$ dan $\mathrm{H}_{2} \mathrm{O}$, sehingga semakin besar respirasi laju pertumbuhan tanaman menjadi berkurang, oleh karena itu peningkatan suhu udara harus dikendalikan (Handoko, 1994).

\section{Strategi Ketahanan Pangan di Sulawesi Utara Dalam Menghadapi Dampak Perubahan Iklim}

Perubahan iklim sangat berpengaruh terhadap rangkaian sistem ketahanan pangan terutama pada sub sistem ketersediaan produksi pangan yang cukup. Untuk mempertahankan ketahanan pangan dalam menghadapi dampak perubahan iklim di wilayah Sulawesi Utara, maka perlu diambil langkah-langkah strategis, yaitu : 1) Kebijakan Pengembangan Industri Pertanian (Agriindustri); 2) Kebijakan Lahan dan Pengembangan Infrastruktur; 3) Pengembangan Kelembagaan Petani; 4) Pengembangan Kawasan; 5) Pengembangan Teknologi Pangan; 6) Diversifikasi Konsumsi Pangan.

\section{KESIMPULAN DAN SARAN}

\section{Kesimpulan}

Berdasarkan hasil penelitian, maka disimpulkan bahwa: 1) Hasil penelitian kebutuhan beras di Provinsi Sulawesi Utara tahun 2013 sebesar $319.018 .304 \mathrm{~kg}$; tahun 2020 sebesar $307.187 .868 \mathrm{~kg}$; tahun 2025 sebesar 305.356 .882 $\mathrm{kg}$; dan tahun 2030 sebesar 304.517.770. 2) Perubahan pola curah hujan dan kenaikan suhu udara mempengaruhi produksi tanaman padi. Kondisi awal produktivitas padi mencapai 6,86 ton/ha, pada kenaikan suhu $1^{\circ} \mathrm{C}$ dan kenaikan curah hujan $5 \%$ produktivitas padi mencapai 6,33 ton/ha, kenaikan suhu $1,5^{\circ} \mathrm{C}$ dan kenaikan curah hujan $35 \%$ produtivitas padi mencapai 5,29 ton/ha, pada kenaikan suhu $2^{\circ} \mathrm{C}$ dan kenaikan curah hujan $25 \%$ produkstivitas padi mencapai 4,55 ton/ha dan pada kenaikan suhu $2,5^{\circ} \mathrm{C}$ dan kenaikan curah hujan $25 \%$ produktivitas padi mencapai 3,54 ton/ha.

\section{Saran}

Perlu adanya penelitian lanjutan tentang data perubahan iklim secara keseluruhan di wilayah Sulawesi Utara

Perlu adanya pengembangan bioteknologi tentang bibit unggul yang tahan terhadap gangguan perubahan iklim

Mengantisipasi perubahan iklim terhadap produksi pangan, maka perlu dilakukan langkahlangkah kebijakan ketahanan yaitu: (a) kebijakan pengembangan industri pertanian (Agriindustri), (b) kebijakanlahan dan pengembangan infrastruktur, (c) pengembangan kelembagaan petani, khususnya kelembagaan cadangan pangan masyarakat, (d) pengembangan kawasan (penataan tata ruang), (e) pengembangan teknologi pangan, dan (f) diversifikasi konsumsi pangan

Perlu adanya penelitian lebih lanjut tentang penggunaan model Shierary Rice terhadap produksi tanaman pangan lainnya

\section{DAFTAR PUSTAKA}

Anonimous. 2011. Padi. http://id.wikipedia.org/ wiki/padi. Diakses tanggal 28 Agustus 2012.

----.-. 2010. Indonesia Climate Change Sectoral, Road Map, ICCSR.

Daniel, B. 2011. Pendugaan Produksi Padi Sawah Tahun 2012-2015 Di Sulawesi Utara Dengan Data Bangkitan Curah Hujan HyBMG. Jurusan Budidaya Pertanian Fakultas Pertanian Unsrat.

Djufri, F., A. Yanto, Handoko, dan Kusmaryono. 2005. Pendugaan Defisit Air Tanaman Jarak (Ricinus communis L). Jurnal Agromet Indonesia. Vol. XIX No. 2 Desember 2005.

Handoko, I. 1994. Dasar Penyusunan dan Aplikasi Model Simulasi Komputer untuk Pertanian, Jurusan Agromet IPB. 112p.

IRRI (International Rice Research Institute). 2004. IRRI's Enviromental Agenda: An Approach Foward Sustainable Development. IRRI, Los Banos, Philippines, 35p. 
Las Insal, H. Syabuddin, E. Surmaini, dan Achmad M. Fagi. 2009. Iklim dan Tanaman Padi: Tantangan dan Peluang. Balai Besar Penelitian Tanaman Padi, Badan Penelitian dan Pengembangan Pertanian. Matthews, R.B. and R. Wassmann. 2003. Modelling The Impact Of Climate Change and Methane Emission Reduction On Rice
Production: A Review. European Journal Of Agronomy 19:573-598.

Rogi, J.E.X. 2002. Penyusunan Model Simulasi Dinamika Nitrogen Pertanaman Kelapa Sawit (Elaeis guineensis Jacg.) Di Unit Usaha Bekri Provinsi Lampung. Disertasi. PPS IPB Bogor. 
